УДК 316.7; 327

Ручка Анатолій Олександрович доктор філософських наук, професор, Інститут соціології НАН Украӥни, Київ, Україна, old.soc@gmail.com

Танчер Віктор Володимирович https://orcid.org/0000-0002-6945-4233 доктор філософських наук, професор, Київський національний університет культури і мистецттв,

Київ, Україна, vtancher@gmail.com

\title{
КОМПЕТЕНТНІСТЬ ЯК ЧИННИК МІЖКУЛЬТУРНОЇ КОМУНІКАЦІЇ В ГЛОБАЛІЗОВАНОМУ СВІТІ
}

Глобалізація світового розвитку актуалізує нові вимоги до міжнародної співпраці. На перший план висуваються запити на компетенції, що забезпечуватимуть успішність міжкультурної комунікації. Становлення глобальної культури, полікультурність сучасних соціумів і крос-культурні практики потребують наявності низки ключових компетентностей, серед яких спілкування різними мовами, обізнаність в інформаційній царині, вміння навчатися тощо. Зокрема, данні соціологічного моніторингу IC НАНУ свідчать про кореляцію між рівнем компетентності та культурною активністю громадян України в сфері вільного часу. Крос-культурна компетентність $є$ важливим ресурсом міжнародного співробітництва. Вона пов'язана 3 повагою до культурних різноманітностей, плюралізмом і толерантністю, які формуються в процесі міжкультурного навчання. Стабільність та прогрес міжнародної співпраці у царині культури залежатимуть від розвинення означених компетентностей.

Ключові слова: компетенції, глобалізація, міжкультурна комунікація, полікультурність соціумів, мультикультуралізм, крос-культурний моніторинг, міжкультурне навчання, культурна толерантність.

Ruchka Anatolii, Doctor of Philosophy, Professor, Institute of Sociology of the National Academy of Sciences of Ukraine, Kyiv, Ukraine

Tancher Victor, Doctor of Philosophy, Professor, Kyiv National University of Culture and Arts, Kyiv, Ukraine.

Competency as intercultural communication factor in a globalized world

The globalization of world development actualizes new requirements for international cooperation. At the forefront are the requests for competencies that 
will ensure the success of intercultural communication. The formation of a global culture, the multiculturalism of modern societies and cross-cultural practices require a number of key competences, including communication in different languages, awareness in the information area, ability to study, etc. In particular, the results of the sociological monitoring of the Institute of Sociology of the National Academy of Sciences indicate a correlation between the level of competence and the cultural activity of Ukrainian citizens in the field of leisure time. Cross-cultural competence is an important resource of international cooperation. It relates to respect for cultural diversity, pluralism and tolerance, being formed in the process of intercultural learning. The stability and progress of international cooperation in the field of culture will depend on the development of the identified competencies.

Key words: competence, globalization, intercultural communication, multicultural societies, multiculturalism, cross-cultural monitoring, intercultural learning, cultural tolerance.

Ручка Анатолий Александрович, доктор философских наук, профессор, Институт соииологии НАН Украины, Киев, Украина

Танчер Виктор Владимирович, доктор философских наук, профессор, Киевский национальный университет культуры и искусств, Киев, Украина.

\section{Компетентность як средство межкультурной коммуникации в глобализованном мире}

Глобализация мирового развития актуализирует новые требования к международному сотрудничеству. На первый план выдвигаются запросы на компетенции, обеспечивающие успешность межкультурной коммуникации. Становление глобальной культуры, поликультурность современных социумов и кросскультурные практики нуждаются в наличии ряда ключевых компетенций, среди которых возможность общения на иностранных языках, грамотность в информационной сфере, способность к обучению и т. д. В частности данные социологического мониторинга ИС НАНУ показывают, что имеет место корреляция между уровнем компетентностей и культурной активностью граждан Украины в сфере свободного времени. Кросскультурная активность является важным ресурсом международного сотрудничества. Она связана с уважительным отношением к культурным различиям, плюрализмом и терпимостью, которые формируются в процессе меж культурного обучения. Стабильность и прогресс международного сотрудничества в области культуры зависят от развития обозначенных компетенций.

Ключевые слова: компетентности, глобализация, межкультурная коммуникация, поликультурность социумов, кросскультурные исследования, межкультурное обучение, культурная толерантность. 


\section{КОМПЕТЕНТНІСТЬ ЯК ЧИННИК МІЖКУЛЬТУРНОЇ КОМУНІКАЦІЇ В ГЛОБАЛІЗОВАНОМУ СВІТІ}

Вступ. Швидкі глобальні перетворення та новітні виклики світовому розвитку висувають нові вимоги до умов співпраці на міжнародному полі. За сучасних обставин людський капітал, котрий формувався раніше, за інших історичних умов, у наш час вже не може адекватно реалізуватися. Про це свідчать сучасні практики міжнародного співробітництва, бізнесу, ринку праці, вимог менеджменту до людських ресурсів. Актуальні життєві ситуації ставлять перед людиною багато питань, невідомих раніш, вимагають компетентних відповідей і рішень, реалізації програм вдосконалення людської життєдіяльності в нових суспільно-історичних умовах, зокрема в гуманітарній царині в глобальному, міжнародному вимірі. Нові виклики потребують нових компетенцій та культурної активності людей.

Кожному соціуму конче потрібні особистості, які вміють вирішувати нагальні кризові проблеми, які володіють сформованими компетенціями щодо правильного оцінювання обставин і формулювання завдань розв язання проблемних ситуацій. При цьому передбачається, що компетентні особи мають бути моральними, відповідальними, здатними до співпраці такими, які можуть приймати креативні рішення, зокрема в міжнародному, міжкультурному співробітництві.

Мета статті - висвітлити стан і перспективи вивчення формування необхідних для успішного міжнародного співробітництва культурних компетенцій.

Аналіз попередніх досліджень і публікацій. Компетентністна проблематика в соціологічних дослідженнях тільки починає розвиватися. Ще існує чимало питань щодо методик емпіричних досліджень компетентностей та їхніх релевантних індикаторів. Втім, українські соціологи з IC НАНУ Н. Костенко і Л. Скокова зробили якісне дослідження, у якому тестували шкалу культурної компетентності, зокрема 3'ясовували сприйняття в Україні інших культур, проаналізували міжкультурну взаємодію тощо (Kostenko, Skokova, 2012). Проте актуальна оцінка рівня культурної компетентності, його динаміки в часі та значення для розвитку міжнародного співробітництва ще чекає свого систематичного дослідження.

Виклад основного матеріалу. Міжнародна i міжкультурна взаємодія розгортається в наш час на тлі процесу глобалізації світу культури.

Як відомо, глобалізація означає посилення взаємозалежності, послаблення кордонів, які склалися історично, стискання як часу, так i простору. Ця взаємозалежність, взаємозумовленість відбувається на всіх соціальних рівнях та в усіх сферах - економічній, культурній, політичній, науковій, екологічній тощо. Водночас, процес глобалізації здійснюється через створення глобальної мережі культурних кодів, символів та значень. Інтернет, мода, реклама, кінематограф, природні катаклізми, політичні події, наукові відкриття, курси валютусі ці різноякісні явища, повідомлення й знаки існують одночасно для усіх, сприймаються усіма однаково та мають відповідний вплив. Завдячуючи глобальним 
засобам масової інформації й мережевій спільності всі живуть у одній системі подій та одній системі смислів (Tancher, 2018).

Таким чином, глобалізація постає як комплекс взаємопов'язаних процесів: економічних, культурних, технологічних, політичних. Наслідком таких процесів $\epsilon$ необмежений плин інформації, образів, ідей, товарів, капіталів, стилів життя, загроз та ризиків через кордони. У поєднанні із виникненням соціальних мереж і політичних інституцій, що обмежують вплив національних держав на життєдіяльність своїх суспільств, - усе це сприяє створенню глобальної культури сучасного світу. За таких умов, культурні процеси, які $є$ дуже важливими для соціального функціювання й визначення ідентичності членів соціумів, слабке контролювання на політичному рівні національними державами. Наднаціональні, глобальні впливи стають більш потужними і визначальними. Звідси виникають не досліджувані раніше проблеми, що постають перед політиками, соціологами культури, керманичами культурного розвитку. Сучасна соціально-політична аналітика свідчить, що в полікультурному (мультикультурному) світі, котрий вступив у період швидкої глобалізації, одразу проявилися проблеми, суперечності і конфліктні зони в царині соціально-культурних відносин, які стали предметом розгляду, темами аналітичних розвідок і дискусій соціальних дослідників. Культурні взаємовпливи, уніфікація культурного споживання, універсалізація норм і цінностей, гібридизація культур тощо виступають помітними наслідками глобалізації, що стрімко набуває визначального чинника сучасного суспільного розвитку. У цьому сенсі можна прийняти визначення глобалізації як процес посилення інтенсивності й глибини взаємодії та взаємозалежності між культурними світами (національно-державними утвореннями, цивілізаційними моделями) у глобальній світ-системі, а це, насамперед, актуалізує проблематику правильного витлумачення таких процесів, компетентних відповідей, прийняття адекватних рішень. Тобто нові виклики часу очікують компетентної культурної активності людей.

Зараз українському соціуму конче потрібні такі люди, які можуть переважно самостійно вирішувати проблемами. Йдеться, таким чином, про людей, які володіють сформованими компетентностями щодо грамотного оцінювання стану життєвих обставин, адекватного формулювання завдань із розв'язання важних проблемних ситуацій. При цьому передбачається, що компетентні люди повинні бути високоморальними, здатними до співробітництва, критично налаштованим, тими, які можуть приймати креативні рішення. Визначено, що компетентність це атрибут професіоналізму, якій у своїй основі має солідну професійну (функціональну) підготовку в межах професійної діяльності людини. Проте компетентність не можна редукувати тільки до реалізації професійної підготовки. Компетентність - ие своєрідний конгломерат. До його складу належить ціла низка інших компонентів поза професійного характеру. І вони, як свідчить практика, конче 


\section{КОМПЕТЕНТНІСТЬ ЯК ЧИННИК МІЖКУЛЬТУРНОЇ КОМУНІКАЦІЇ \\ В ГЛОБАЛІЗОВАНОМУ СВІТІ}

потрібні сучасній молоді. Йдеться, передусім, про соціальну, мовну, крос-культурну, діджітальні, креативні та інші компетентності (Ruchka, 2017).

Отже, компетентності не можна зводити до якогось (одного) окремого компонента, який сам по собі є необхідним для виконання певної життєдіяльності. Компетентність - це не тільки якісь посадові чи професійні повноваження, якесь спеціалізоване знання, якісь кваліфікації, уміння, здібності. Компетентність $\epsilon$ сукупністю (єдністю) певних компонентів, таких як знання, уміння, кваліфікація, повноваження, настанови, ціннісно-смислові позицї, які разом забезпечують досягнення запланованих результатів (цілей, цінностей). У такому ключі компетентність може виступати відносно усталеною характеристикою окремих людей, окремих соціально-професійних категорій, окремих організацій, спільнот, угрупувань, соціально-культурних середовищ, населення країни в цілому.

Значимість компетентності, таким чином, можна розглядати на трьох рівнях: micro (індивід), теzzо (організація), тасro (суспільство). Особливо цінними є ті компетентності, реалізація яких на практиці приносить користь водночас як у сфері особистого чи професійного життя, так і суспільству в цілому. У соціологічній літературі компетентності визначаються як ключові компетентності. У цьому відношенні, до речі, Рада і Парламент Свропи прийняли в 2006 р. Свропейські рамки ключових компетентностей, котрі формуються в процесі неперервного навчання протягом всього життя. У цих рамках визначаються компетентності, які необхідні громадянам (європейцям) для їх самореалізації, активної громадянської позиції і набуття шансів на ринку праці в сучасному суспільстві. При цьому підкреслюється, що системи освіти в країнах ЕС повинні підтримувати формування таких компетентностей у всіх молодих людей. Водночас різні програми та інститути повинні й дорослим створювати можливість навчання та отримання означених компетентностей і умінь.

Європейські рамки компетентностей охоплюють вісім ключових компетентностей, які передбачають реалізацію наступних знань і умінь: спілкуватися рідною мовою, спілкуватися чужою мовою, бути обізнаним в інформаційній сфері, володіти математичними і основними науково-технічними знаннями $і$ навичками, вміти навчатися, вміти користуватися сочіальними і громадськими можливостями, бути ініціативними $i$ підприємливими; бути культурно усвідомленими $i$ креативними (Pro osnovni kompetentsii dlia navchannia ...).

Усі означені ключові компетентності є однаково важливими, адже кожна 3 них має позитивно сприяти успішній життєдіяльності.

Загалом будь-які компетентності людини можуть здійснюватися в декількох узагальнюючих аспектах: когнітивному, поведінковому і мотиваційному. Когнітивний аспект пов'язаний зі знаннями, пізнавальним процесом, охоплює логічне, інтуїтивне, креативне мислення. Поведінковий аспект пов’язаний з умінням, 
навичками, кваліфікаціями, здібностями людей, які мають прояв у ефективних діях, спрямованих на досягнення певних цілей. Мотиваційний аспект грунтується на мотивації життєвої чи професійної активності людей, їхніх настановах i готовності до реалізації певних цілей. Суттєве значення тут мають інтерналізовані ціннісно-смислові позиції, що постають у вигляді стандартів життєвої активності, зокрема й iї мотивації.

Якщо зауважити, що компетентність високого рівня завжди грунтується на поєднанні когнітивного, мотиваційного і поведінкового аспектів, то тоді можна дійти наступних висновків. Володіння тільки певним знанням ще не означає, що людина $є$ достеменно компетентною. Але присутність певного знання в даному відношенні є обов'язковим, бо воно є науково обгрунтованою основою практичних умінь у певній ситуації. Зі свого боку, уміння виступають як кваліфікації та здатності, що зумовлюють ефективне використання знань задля виконання поставлених завдань і розв'язання існуючих проблем. Проте тому чи тому може сприяти (або ні) мотиваційна сторона компетентності, яка на підставі ціннісносмислового тлумачення визначає зацікавленість певним знанням і готовність до його практичного застосування (через реалізацію умінь, здібностей, кваліфікацій). Це означає, що даний мотиваційний аспект, який $\epsilon$ в цілому суб'єктивною складовою життєвої активності людей, грає сьогодні, мабуть, вирішальну роль як у формуванні, так і реалізації їхньої компетентності.

У сучасних соціумах будь-яка життєва компетентність може розглядатись як культурна компетентність. Оскільки в межах певної культури життєва компетентність повинна враховувати відповідні цінності і зразки, що історично вироблені в даній культурні для розв'язання типових життєвих проблем. Зрозуміло, типові життєві проблеми та технології їх розв'язання 3 часом змінюються. Наприклад, ті ключові компетентності, які прийняв у 2006 р. Європейський Парламент, спрямовані на розв'язання проблемних ситуацій, які виникають у зв'язку 3 викликами постмодерного, інформаційного суспільства. Усі зазначені ключові компетентності вважаються (в європейських рамках) однаково важливими, бо кожна 3 них може сприяти нормальному життю в суспільстві знань. Сфери ключових компетентностей перетинаються одна 3 одною, частково співпадають між собою, й тому вони переважно взаємодоповнюють одна одну. Так, уміння в сфері інформаційних i комунікативних технологій $\epsilon$ необхідною умовою процесу навчання; вміння навчатися сприяе підвищенню компетентності в інших сферах людської активності. Деякі елементи чи характеристики притаманні усім ключовим компетентностям. Це стосується розвитку критичного мислення, креативності, ініціативності, розв'язування проблемних ситуацій, оцінок ризиків, конструктивного керування емоціями. Досягнення нормативного рівня ключових компетентностей, а також ї складових, можна дійсно розглядати як ресурс підвищення людського капіталу, його креативного розвитку в цілому. 


\section{КОМПЕТЕНТНІСТЬ ЯК ЧИННИК МІЖКУЛЬТУРНОЇ КОМУНІКАЦІЇ В ГЛОБАЛІЗОВАНОМУ СВІТІ}

У широкому (антропологічному) розумінні означені ключові компетентності $\epsilon$ культурними. За своїм походженням вони є культурними артефактами або ментефактами. У вузькому розумінні культурна компетентність визначається як комплекс набутих рис, здатностей, знань, умінь і ціннісних орієнтацій, які дають людині вільно приймати участь у культурі, проявляти відповідну культурну активність. Отже, культурна компетентність у цьому випадку передбачає, що людина має не тільки знання та систематичні уявлення про цю (напр., вітчизняну) культуру, але вона також здатна прийняти, засвоїти через інтерналізацію іiі цінності, норми і смисли. Розвиток культурної компетентності щільно пов'язаний із формуванням культурної ідентичності людей.

При операціональному використанні поняття культурної компетентності можна аналітично виділяти іiі «активні» і «пасивні» аспекти. Перші пов'язані 3 активною культурною партиципацією (участю), культурною експресією (чуттєвістю), проявом нормативної культурної ідентичності. Інші обмежуються, зазвичай, набуттям тільки певної сукупності знань про культуру, пасивною культурною участю, коли люди виступають переважно як глядачі, слухачі, споживачі. Зрозуміло, що за умов глобалізації, швидкої зміни соціокультурних реалій культурна компетентність наповнюється не тільки новим змістом. Вона стає також схильною до плюралізації, мультиплікації нових своїх різновидів. Так, 3'являються мережева компетентність, компетентність у сфері пропозицій медіа та культурного споживання, компетентність у сфері адаптації до сучасних змін, еко-культурна компетентність тощо.

Щодо форм культурної активності, то їх можна певних чином кваліфікувати відповідно ментальних і поведінкових контактів, які здійснює людина з існуючою культурною. Вона, по-перша, може читати пресу, слухати радіо, спостерігати культурні явища тощо. По-друге, вона також може аналізувати, наприклад, літературні твори, міркувати про художні твори, дискутувати на різні теми тощо. По-третє, людина може приймати участь як аматор у культурних заходах, наприклад, співати або танцювати в клубі перед публікою. По-четверте, разом з іншими людина може просувати, пропагувати якусь культурну тематику, моду, художні рухи тощо. По-п'яте, за власною ініціативою людина може поширювати серед широкого загалу якісь культурні проекти та ін. По-шосте, людина може активно брати участь, наприклад, у художній самодіяльності, займатися спортом, хобі та ін. По-сьоме, сьогодні людина може активно і творчо приймати участь у мережевій комунікації, висловлюючи свої оцінки і судження щодо культурних явищ і подій.

Зрозуміло, що людина усе перераховане може робити одночасно. Але найчастіше люди віддають перевагу певним ментальним i поведінковим контактам з культурою. У нашому випадку перспективним $є$ порівняння змістовних форм культурної активності (занять людей у вільний від основної та домашньої 
роботи час) між громадянами 3 відносно високим і низьким рівнем життєвої компетентності.

Нижче наведені дані, які засвідчують профілі культурної активності двох угрупувань українських громадян у залежності від рівня їхньої життєвої компетентності - компетентних і малокомпетентних.

Таблиця 1

\section{Профілі культурної активності двох угрупувань українських громадян}

Форма культурної

активності

Просоціальні повсякденні

комунікації

Когнітивно-інформаційні

заняття

Практики рекреаціï

та відпочинку

Релігійні практики

Культурно-розважальні

заняття
Компетентні громадяни

$$
(n=681)
$$

$53,9 \%$

$33,9 \%$

$32,3 \%$

$25,3 \%$

$21,6 \%$
Малокомпетентні громадяни $(\mathrm{n}=596)$

$35,9 \%$

$26,7 \%$

$20,0 \%$

$21,3 \%$

$8,6 \%$

Як бачимо, різні рівні життєвої компетентності обумовлюють різний рівень означених форм культурної активності наших людей. Згідно усіх блоків культурної активності у вільний від основної та домашньої роботи час компетентні респонденти випереджають малокомпетентних. При цьому, з блоку «Просоціальні повсякденні комунікації» це випередження є статистично значимим $(\mathrm{t}=4,30)$. Те саме стосується блоків «Культурно-розважального заняття» $(\mathrm{t}=2,50)$ i «Практики рекреації та відпочинку» (t=2,54). Отже, компетентні громадяни суттєво випереджають малокомпетентних за соціальними повсякденними комунікаціями, практиками рекреації та відпочинку і культурно-розважальним заняттям. Щодо когнітивноінформаційних занять i релігійних практик, їх рівень у компетентних і малокомпетентних громадян практично однаковий.

Водночас отримані соціологічні дані показують, що в межах культурнорозважального блока занять компетентні статистично значуще випереджають малокомпетентних за такими заняттями як відвідування кінотеатрів $(\mathrm{t}=2,46)$, прослуховування музики $(\mathrm{t}=5,0)$, хобі $(\mathrm{t}=1,97)$, відвідування торговельнорозважальних центрів $(\mathrm{t}=3,87)$, відвідування кафе, барів, дискотек $(\mathrm{t}=4,18)$. Випередження компетентних громадян за такими заняттями цього блоку як відвідування концертів і театрів $(\mathrm{t}=1,77)$, відвідування музеїв, художніх виставок, галерей $(\mathrm{t}=1,02)$, електронні комп'ютерні ігри $(\mathrm{t}=1,62)$, відвідування ресторанів, нічних клубів $(\mathrm{t}=1,38)$ не $є$ статистично значущим. 


\section{КОМПЕТЕНТНІСТЬ ЯК ЧИННИК МІЖКУЛЬТУРНОЇ КОМУНІКАЦІЇ В ГЛОБАЛІЗОВАНОМУ СВІТІ}

У межах блоку практик рекреації та відпочинку компетентні статистично значуще випереджають малокомпетентних за такими практиками як активні заняття фізкультурою та спортом ( $\mathrm{t}=308)$, турбота про зовнішній вигляд $(\mathrm{t}=1,95)$ рибальство, мисливство і відпочинок на природі $(\mathrm{t}=2,47)$, поїздка на відпочинок, курорт, подорож $(\mathrm{t}=3,88)$. А от випередження компетентних громадян за відпочинку вдома не $\epsilon$ статистично значимим $(\mathrm{t}=1,02)$. Що стосується когнітивно-інформаційних занять, то тут компетентні статистично суттєво випереджають малокомпетентних за таким заняттям, як користування Інтернетом $(\mathrm{t}=6,85)$. За іншим заняттям цього блокучитання газет, журналів $(\mathrm{t}=0,43)$, фахової літератури $(\mathrm{t}=1,39)$, художньої літератури $(\mathrm{t}=1,38)$, перегляд телепередач $(\mathrm{t}=0,61) \quad-\quad$ випередження компетентних не є статистично значимим.

Отже, в цілому, громадяни 3 відносно високим рівнем життєвої компетентності випереджають малокомпетентних за 11-ма заняттями із 23-х, що становить 47,8 \% випадків. У 52,2 \% випадків компетентні й малокомпетентні громадяни мають практично однаковий рівень культурної активності у вільний від основної та домашньої роботи час. Це означає, що відносно високий рівень життєвої компетентності може справді виступати значущим каталізатором культурної активності наших громадян у сфері вільного часу (Kostenko, Skokova, 2012).

Таку кореляцію рівня компетенції з культурною активністю можна 3 великою вірогідністю поширити на міжкультурну комунікацію, тобто - чим краще ми ознайомлені 3 іншими культурами, тим легше i успішніше міжкультурне співробітництво.

За умов сьогоднішньої культурної різнорідності, коли загострюються питання захисту національно-культурної ідентичності та, водночас, просування різнорідних форм культурної глобалізації, особливого значення набуває міжкультурна компетентність. Ця компетентність пов'язується 3 процесом формування у людини розуміння культури Інших. Вона базується на усвідомленні того, що різнорідність (різноманітність) - це об’єктивна характеристика світової культури i рушійна сила iї розквіту. Отже, міжкультурна компетентність це не тільки чинник адаптації до різнорідності, уникнення виключення та маргіналізації Інших, заохочення толерантності та солідарності в сучасних суспільствах. Полікультурність виступає також ресурсом розвитку, який може перетворитися в людський капітал, слугуватиме підмурком для творчості, креативу, оригінального розв'язування життєвих проблем завдяки перенесенню тих чи тих елементів із одних культурних контекстів у інші.

Розвинута міжкультурна компетентність містить у собі повагу до чужих точок зору, традицій, культур, а також бажання вирішувати мирним шляхом будь-які конфлікти. Люди 3 такою компетентністю володіють, зазвичай, здатністю бачити себе на місці інших людей, навіть асоціюватися 3 ними, приймати як свої їхні переконання і погляди. У сучасних суспільствах таких людей незрівнянно більш, 
ніж у колишніх (суто традиційних) соціумах. Адже, з одного боку, люди сьогодні досить часто міняють соціальні ролі, а 3 другого, - сучасний культурний обмін, діалог культур, культурна взаємодія породжують здатність людей до вживання в чужі культури, проникнення в чужі погляди, вірування, переконання. Усе це сприяє так чи так формуванню толерантної крос-культурної компетентності.

Визначальну роль у цьому процесі мусить відіграти міжкультурне навчання, розвиток міжкультурного комунікативного потенціалу. Таке навчання сприятиме відкритості до інших, толеруванню відмінностей, взаєморозумінню, рівним можливостям та антидискримінації. Адже це $є$ одним з основоположних принципів Європейського союзу.

Висновок. Отже, якщо полікультурність (багатокультурність) є властивістю не тільки окремих соціумів, але й цілого світу, то сьогодні належить підвищувати не тільки культурну компетентність, але й крос-культурну також, тобто виробляти здатність розрізняти і розуміти різні культурні коди, культурні спадщини, різноманітні культурні втілення. Це потрібно для того, щоб налагоджувати комфортну, взаємокорисну міжкультурну комунікацію, протидіяти ексклюзії (виключенню) та маргіналізації Інших, усувати міжкультурну напругу загалом.

\section{References:}

1. Kostenko, N., Skokova, L. (2012). 'Testuvannia shkaly kulturnoi kompetntnosti (CQS): ukrainska audytoriia' [Testing of the cultural competence scale: Ukrainian audience]. Sotsiolohiia: teoriia, metody, marketynh [Sociology: theory, methods, marketing], no. 4, pp. 231-234.

2. Pro osnovni kompetentsii dlia navchannia protiahom usoho zhyttia: Rekomendatsiia 2006/962/IeS vid 18 hrudnia 2006 roku [Main recommendations on key competences for lifelong learning: Recommendation 2006|962| EU (2006, December 18)]. Verkhovna Rada of Ukraine, [online] Available at: $<$ http //zakon2.rada.gov.ua/law/show/994-975> [Accessed 25 October 2018].

3. Ruchka, A. O. (2017). 'Kompetentnist yak resurs zhyttievoi aktyvnosti' [Competences as resource of live activity]. Ukrainske suspilstvo: monitorynh sotsialnykh zmin [Ukrainian society: monitoring of social changes], issue 4(18), pp. 264-276.

4. Tancher, V. V. (2018). 'Polikulturnist suchasnykh sotsiumiv: trendy ta vyklyky' [Polyculturalism of modern socium: trends and challenges]. Mizhnarodni vidnosyny: teoretyko-praktychni aspekty [International Relations: Theory and Practical Aspects], Vol. 1, pp. 219-230. DOI: https://doi.org/10.31866/2616-745x.1.2018.142003.

() Ручка А. О., Танчер В. В., 2019 